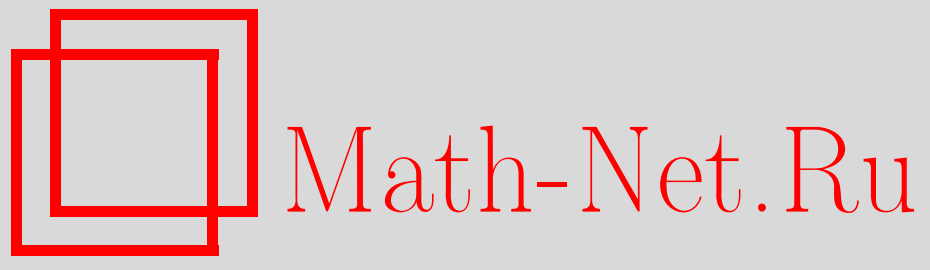

K 75-летию А. А. Новикова, Теория вероятн. и ее примен., 2020, том 65, выпуск 4, 805

DOI: https://doi.org/10.4213/tvp5446

Использование Общероссийского математического портала Math-Net.Ru подразумевает, что вы прочитали и согласны с пользовательским соглашением http://www . mathnet.ru/rus/agreement

Параметры загрузки:

IP : 54.157 .27 .8

26 апреля 2023 г., $14: 19: 56$

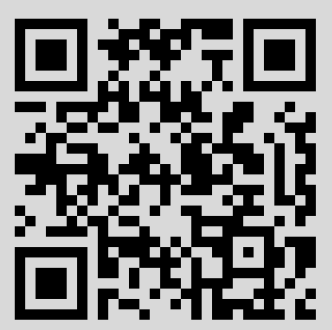




\section{К 75-ЛЕТИЮ А. А. НОВИКОВА}

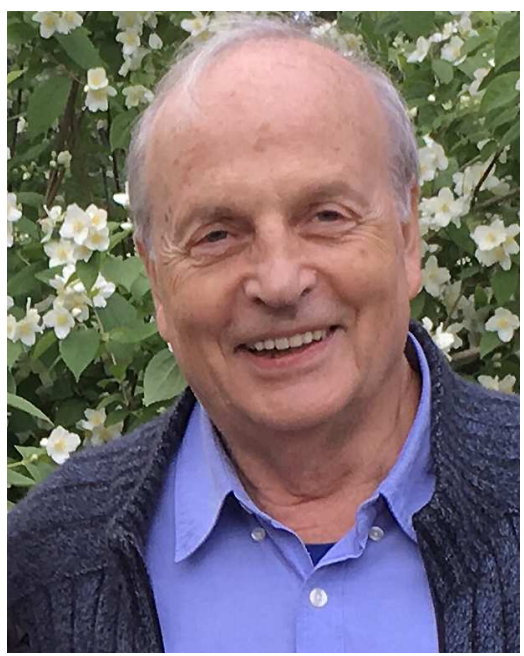

22 июня 2020 г. исполнилось 75 лет выдающемуся ученому, доктору физикоматематических наук, профессору

\section{Александру Александровичу Новикову.}

Его интересы охватывают многие области теории вероятностей, математической статистики, теории случайных процессов, особенно броуновского движения. Широко известны и постоянно цитируются "условие Новикова", установленные им неравенства для максимума стохастических интегралов, оптимальные свойства последовательных оценок, свойства моментов выхода броуновского движения на криволинейные границы, результаты по теории мартингалов и многое другое.

Редакционная коллегия журнала "Теория вероятностей и ее применения" сердечно поздравляет Александра Александровича, автора многочисленных статей в нашем журнале, с юбилеем и желает ему крепкого здоровья и дальнейших творческих успехов. 